Louisiana State University

LSU Digital Commons

Faculty Publications

Department of Oceanography \& Coastal

Sciences

2014

\title{
The Economics Of Dead Zones: Causes, Impacts, Policy \\ Challenges, And A Model Of The Gulf Of Mexico Hypoxic Zone
}

\author{
S S. Rabotyagov \\ rabotyag@uw.edu \\ C. L. Kling \\ ckling@iastate.edu \\ P. W. Gassman \\ pwgassma@iastate.edu \\ Nancy N. Rabalais \\ Louisiana State Univ, Dept Oceanog \& Coastal Sci, nrabalais@lumcon.edu \\ R. Euigene Turner \\ euturne@lsu.edu
}

Follow this and additional works at: https://digitalcommons.Isu.edu/oceanography_coastal_pubs

\section{Recommended Citation}

Rabotyagov, S. S., Kling, C. L., Gassman, P. W., Rabalais, N. N., \& Turner, R. (2014). The Economics Of Dead Zones: Causes, Impacts, Policy Challenges, And A Model Of The Gulf Of Mexico Hypoxic Zone. Review Of Environmental Economics And Policy, 8 (1), 58-79. https://doi.org/10.1093/reep/ret024

This Article is brought to you for free and open access by the Department of Oceanography \& Coastal Sciences at LSU Digital Commons. It has been accepted for inclusion in Faculty Publications by an authorized administrator of LSU Digital Commons. For more information, please contact ir@lsu.edu. 


\title{
The Economics of Dead Zones: Causes, Impacts, Policy Challenges, and a Model of the Gulf of Mexico Hypoxic Zone
}

\author{
S. S. Rabotyagov*, C. L. Kling ${ }^{\dagger}$, P. W. Gassman*, N. N. Rabalais ${ }^{\S}$ \\ and R. E. Turner
}

\section{Introduction}

The BP Deepwater Horizon oil spill in the Gulf of Mexico in 2010 increased public awareness and concern about long-term damage to ecosystems, and casual readers of the news headlines may have concluded that the spill and its aftermath represented the most significant and enduring environmental threat to the region. However, the region faces other equally challenging threats including the large seasonal hypoxic, or "dead," zone that occurs annually off the coast of Louisiana and Texas. Even more concerning is the fact that such dead zones have been appearing worldwide at proliferating rates (Conley et al. 2011; Diaz and Rosenberg 2008). Nutrient overenrichment is the main cause of these dead zones, and nutrient-fed hypoxia is now widely considered an important threat to the health of aquatic ecosystems (Doney 2010).

The rather alarming term dead zone is surprisingly appropriate: hypoxic regions exhibit oxygen levels that are too low to support many aquatic organisms including commercially desirable species. While some dead zones are naturally occurring, their number, size, and

${ }^{\star}$ School of Environmental and Forest Sciences, University of Washington, Seattle, Washington, USA; e-mail: rabotyag@uw.edu

${ }^{\dagger}$ Center for Agricultural and Rural Development, Department of Economics, Iowa State University, Ames, Iowa, USA; e-mail: ckling@iastate.edu

Center for Agricultural and Rural Development, Department of Economics, Iowa State University, Ames, Iowa, USA; e-mail: pwgassma@iastate.edu

${ }^{\S}$ Louisiana Universities Marine Consortium, Chauvin, Louisiana, USA; e-mail: nrabalais@lumcon.edu

'Department of Oceanography and Coastal Sciences, Louisiana State University, Baton Rouge, Louisiana, USA; e-mail: euturne@lsu.edu

This work was supported in part by the National Science Foundation, Dynamics of Coupled Natural and Human Systems Program, award number DEB-1010259, by the USDA-NIFA, Coordinated Agricultural Project, award number 2011-68002-30190, and the USDA Policy Research Center at Iowa State University. We thank two anonymous reviewers for their helpful suggestions. Suzy Leonard provided outstanding editorial assistance. helping to produce a more coherent and readable document.

Review of Environmental Economics and Policy, volume 8, issue 1, 2014, pp. 58-79 doi:10.1093/reep/ret024

(C) The Author 2014. Published by Oxford University Press on behalf of the Association of Environmental and Resource Economists. All rights reserved. For Permissions, please email: journals.permissions@oup.com 
duration have exploded due to anthropogenic nutrient contributions from agricultural, municipal, and industrial sources.

The issues related to hypoxic conditions - uncertainty and potential irreversibility, spatial interdependence of individual decisions and associated externality damages, transboundary pollution problems, valuation of poorly understood ecosystem services, and the generation of pollutants from nonpoint sources ${ }^{1}$ over vast agricultural landscapes — provide fertile ground for environmental economics research. This article reviews and analyzes the issues related to worldwide hypoxic zones and the range of economic questions sorely in need of answers. First, we describe what is known about the extent and causes of major hypoxic zones worldwide. Second, we review the evidence concerning the impacts of hypoxic conditions on ecosystem services, followed by a brief description of the existing literature on costs and policy options for the mitigation of hypoxic conditions. Third, we analyze the large seasonally recurring hypoxic zone in the northern Gulf of Mexico (NGOM) using a simple statistical model that estimates the relationship between pollutants (nutrients) and the size of the hypoxic zone. This "production function" suggests that both instantaneous and historical nutrient contributions affect the size of the zone and illustrates the usefulness of the cross-fertilization of ideas between economics and ecological science. We use the estimated relationship between nutrient pollution and the size of the hypoxic zone to comment on the existing policy goals for addressing hypoxia in the NGOM. Lastly, we conclude with a discussion of the types of research and cooperation across disciplines that are needed to support the development of policies to address this important ecological and economic issue.

\section{An Overview of the Extent and Causes of Hypoxic Zones}

The term hypoxia refers to oxygen deficiency and is more formally defined as water containing less than $2 \mathrm{mg} / \mathrm{L}$ of oxygen. ${ }^{2}$ Hypoxic zones have occurred naturally in both coastal ocean and freshwater areas that have the requisite combination of weather patterns, ocean geography, currents, and nutrients. However, human activities have caused the magnitude and extent of hypoxic zones around the world to increase dramatically over the past fifty years (Diaz and Rosenberg 1995, 2008). Prior to 1970, there were only scattered reports of coastal hypoxic zones in Europe and North America in the literature (Rabalais et al. 2010). However, by 1995, Diaz and Rosenberg (1995) reported over 195 cases worldwide. This number doubled to just over 400 zones by the time Diaz and Rosenberg completed their 2008 review, and an additional 115 sites in the Baltic Sea were added to the list in 2011 (Conley et al. 2011). Figure 1 indicates the location of documented hypoxic zones around the world and would appear to support the contention by Diaz and Rosenberg (2008) that coastal hypoxic zones are primarily located downstream of major population centers and/or land impacted by agriculture.

About half of the hypoxic zones around the world are seasonal-that is, oxygen depletion occurs in spring and summer following the increase in phytoplankton that results from nutrient enrichment. Seasonal hypoxic zones usually last from a few weeks to several months; however, in some locations, about 8 percent worldwide (Diaz and Rosenberg 2008), hypoxic conditions

\footnotetext{
${ }^{1}$ Nonpoint source pollution refers to sources that are diffuse in nature. Common examples include agricultural fields and urban runoff where the precise location of the pollutant's origin is difficult to identify.

${ }^{2}$ Anoxia means there is no oxygen.
} 


\section{World Hypoxic and Eutrophic Coastal Areas}

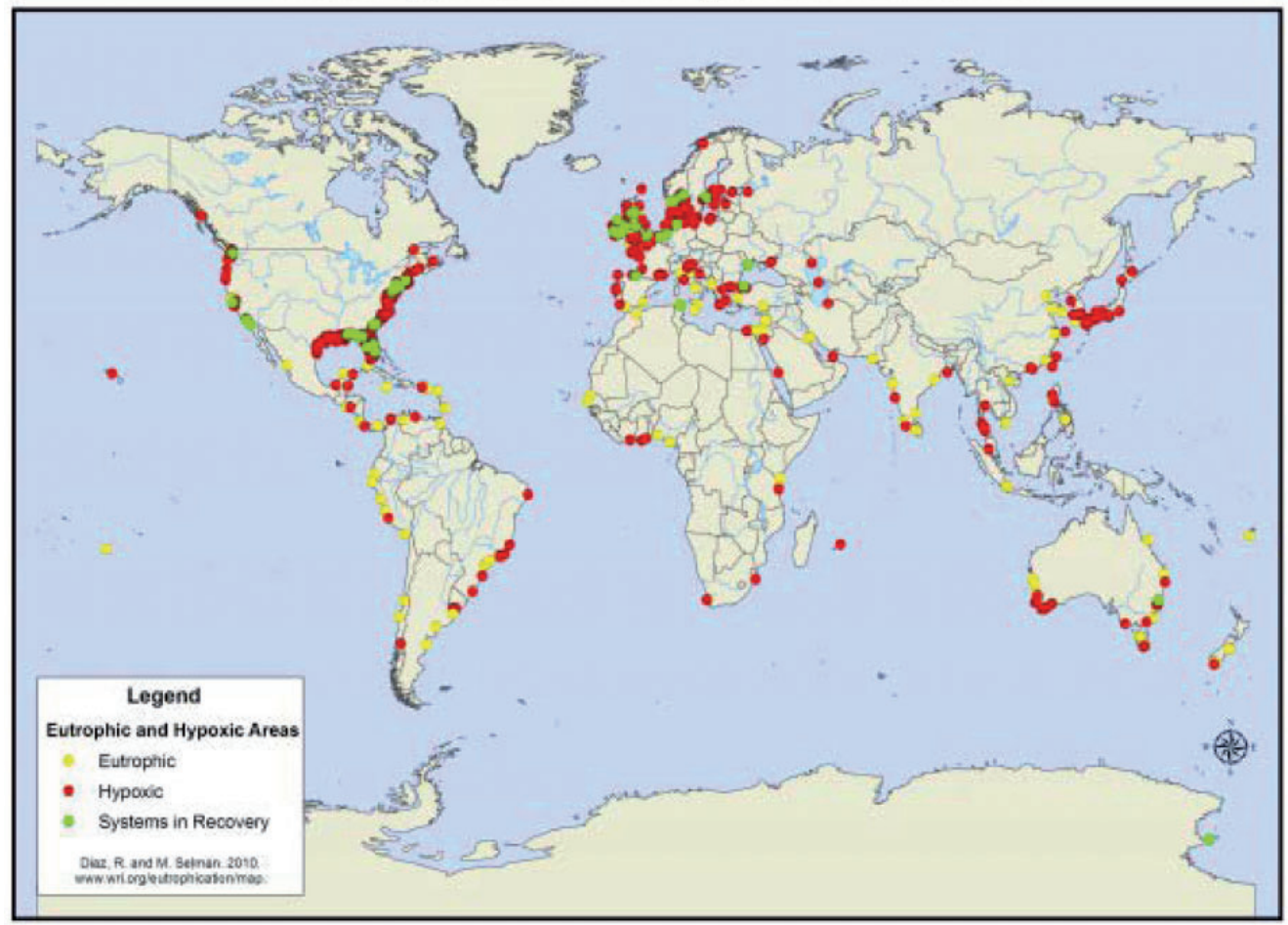

Figure I Location and size of worldwide hypoxic zones

Source: World Resources Institute (http://www.wri.org/sites/default/files/world_2Idec2010.jpg), based on Diaz, R. J., M. Selman, and C. Chique-Canache. 2010. Global Eutrophic and Hypoxic Coastal Systems: Eutrophication and Hypoxia-Nutrient Pollution in Coastal Waters. World Resources Institute, Washington, DC. http://www.wri.org/project/eutrophication

occur continuously throughout the year. The size of annually recurring hypoxic zones can vary significantly from year to year. For example, the NGOM hypoxic zone (Figure 2) has ranged from $40 \mathrm{~km}^{2}$ in the drought year of 1988 to more than $20,000 \mathrm{~km}^{2}$ in both 2001 and 2008 (measurements were initiated in 1985).

\section{Role of Nutrient Enrichment}

The anthropogenic causes of hypoxia are linked to nutrient use (nitrogen and phosphorus) in agricultural production, cropping of leguminous plants, wastewater from human populations and industrial sources, and the burning of fossil fuels. There is three times as much reactive nitrogen and phosphorus being dispersed into the world's oceans today as during preindustrial times (Rabalais et al. 2010; Turner, Rabalais, and Justić 2012). While nutrients are valuable inputs to agricultural production, they become externalities when exported to local waterways via runoff from farm fields, urban landscapes, or municipal wastewater, and transported further downstream to freshwater lakes, estuaries, coastal ecosystems, and the ocean. Once deposited at these locations, the nutrients feed the growth of phytoplankton. This process of increased carbon production and accumulation in an aquatic ecosystem is known as eutrophication (Nixon 1995) and has a number of negative effects on ecosystems 


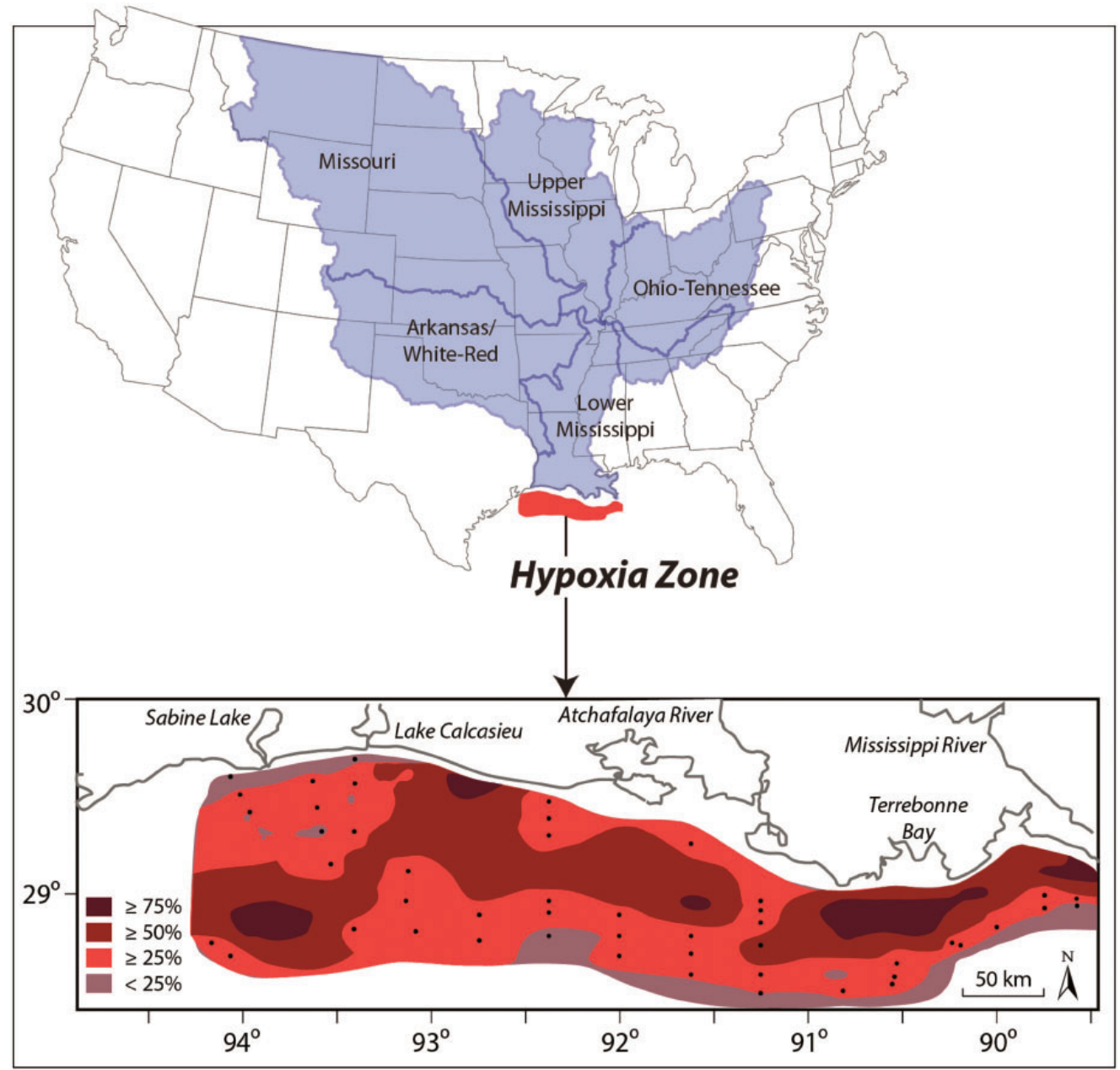

Figure 2 Gulf of Mexico drainage basin (Mississippi-Atchafalaya River Basin)

Notes: Inset: Frequency of midsummer bottom-water hypoxia $\left(\leq 2 \mathrm{mg} / \mathrm{L} \mathrm{O}_{2}\right)$ off the coast of Louisiana and Texas for 60 to 80 stations (small dots) sampled during the summer from 1985 to 2008 . Horizontal axis: degrees of longitude West. Vertical axis: degrees of latitude North.

Source: N. N. Rabalais, Louisiana Universities Marine Consortium (LUMCON).

including noxious and toxic algal blooms, oxygen deficiency, unpleasant odors, habitat alterations, and the degeneration of both aesthetic and economic values. Oxygen depletion occurs as the plant material (i.e., the phytoplankton) dies, falls through the water column, and decomposes in the bottom water layer and sediments. ${ }^{3}$

Nitrogen and phosphorus both contribute to eutrophication. ${ }^{4}$ In some hypoxic zones nitrogen is clearly the limiting nutrient, in others it is phosphorus, and in some it appears to be both (Quigg et al. 2011; Savchuk and Wulff 2009; Turner and Rabalais 2013), often leading

\footnotetext{
${ }^{3}$ The process of decomposition results in reduced oxygen levels if the consumption of oxygen by aerobic bacteria exceeds the re-aeration rate.

${ }^{4}$ However, plants respond to these inputs in fixed proportions. That is, they exhibit a Leontief-style production function that stipulates that factors of production are not substitutable. Ecologists refer to this as Liebig's law of the minimum (van der Ploeg, Böhm, and Kirkham 1999). For example, in simplified terms, growth could be
} 
to a debate concerning which nutrient is driving eutrophication and the resulting hypoxic conditions (Conley et al. 2009).

\section{A Natural Experiment in the Black Sea}

Since the early 1960s a natural experiment has occurred on the northwestern shelf of the Black Sea that demonstrates the role of anthropogenic factors in hypoxia formation and has allowed researchers to observe the ecosystem's response over time (first to increased nutrient loads and then to a subsequent rapid decline in nutrients).

Agricultural and industrial activity expanded rapidly around the Black Sea in the 1960s, especially in the Danube River watershed, resulting in increased nutrient influxes and eutrophication. There were harmful algal blooms, fish kills, and an expanding hypoxic zone (Mee, Friedrich, and Gomoiu 2005; Selman et al. 2008), measuring 3,500 $\mathrm{km}^{2}$ in summer 1973, increasing tenfold by 1978 , and peaking at $40,000 \mathrm{~km}^{2}$ in the late $1980 \mathrm{~s}$. During this period, the fishery that once supported over twenty-five species of commercially valuable fish, worth roughly $\$ 2$ billion, was reduced by 90 percent. Other economic impacts included an estimated loss of $\$ 500$ million in tourism revenue (Battaglini, Plonka, and Merla 2008). While studies assessing the nonmarket impacts of eutrophication are not available, it is likely that the health effects, ${ }^{5}$ lost recreation opportunities, biodiversity losses, aesthetic concerns, and other ecosystem losses were significant. In short, by the early 1990s, very few of the signature attributes of this once diverse and productive ecosystem remained.

With the collapse of the Soviet Union and the restructuring of the economies adjoining the Black Sea that followed in the early 1990s, there were dramatic reductions in fertilizer use and a rapid decline in the size of the hypoxic zone. In fact, almost no discernible hypoxic zone remained by 1995, although there was a temporary setback in 2001 when a late rainfall and high temperatures triggered a hypoxic event (Mee et al. 2005). The case of the Black Sea is unique in that it not only demonstrates how hypoxia increases with increased nutrient influxes, but also shows that the situation can be reversed by cutting nutrient loadings, although the worldwide trend is of increasing nutrient loadings accompanied by increased hypoxia (Diaz and Rosenberg 2008).

\section{Impacts of Hypoxic Conditions on Ecosystem Services}

Scientific understanding is increasing regarding the impacts of hypoxia on ecosystem services and the resulting changes in welfare; however, much remains unknown. Barbier (2012) provides a recent review of the challenges of identifying and valuing ecosystem services in coastal zones. As indicated in the earlier discussion of the Black Sea, there is compelling evidence that the delivery of nutrients can have substantial negative effects on valuable ecosystem services. However, the evidence is less clear in other cases (Breitburg et al. 2009b). Moreover, there are some examples of beneficial effects, at least in the short run, from nutrient delivery, hypoxia, or both (Breitburg et al. 2009a, 2009b). Ideally, studies would identify and describe the effects of hypoxic conditions on the full set of ecosystem services, as described in the Millennium

represented as $g=\min (\alpha N, \beta P)$. As long as $\alpha N<\beta P$, additions of $P$ would not increase production, and $N$ would be called the limiting nutrient.

${ }^{5}$ More than twenty thousand cases of serious waterborne illness were reported (Battaglini et al. 2008). 
Ecosystem Assessment (2005) (supporting, provisioning, regulating, and cultural services). However, the focus of most assessments to date has been on the effects of nutrient loading and hypoxia on individual species and commercial and recreational fisheries (e.g., Breitburg et al. 2009a). Notably absent from the literature are studies that address lost nonuse or existence values associated with hypoxic conditions and eutrophication. Moreover, a full accounting of the welfare effects of nutrient loading requires consideration of the effects at each step (i.e., the initial loading of nutrients to waterways, which are often far upstream of the hypoxic zone location, the ensuing freshwater eutrophication, and the coastal system eutrophication that may create dead zones). We focus here on ecosystem services lost downstream; however, externality damages often begin at the source of the nutrient loadings and can occur throughout the system (Science Advisory Board [SAB] 2007; US Department of Agriculture-Natural Resources Conservation Service [USDA-NRCS] 2012).

\section{Impacts of Nutrient Overenrichment on Aquatic Ecosystems}

Over the past fifty years, human use of nitrogen and phosphorus has been at two to three times the historical levels and has had increasingly negative impacts on ecosystems. However, it can be difficult to distinguish the effects of nutrient enrichment and the resulting hypoxia from changes in fishing methods and intensity, altered habitat and hydrology, natural variability, and additional human-influenced changes in ecosystems (Breitburg et al. 2009a; Caddy 2001; Chesney and Baltz 2001).

Our current understanding of the impacts of hypoxic conditions on organisms, populations and communities, and ecosystem function is summarized in several reviews (Diaz and Rosenberg 2008; Levin et al. 2009; Rabalais et al. 2010) and a book (Rabalais and Turner 2001). Nutrient overenrichment can cause individual organisms to experience a range of behavioral and physiological impacts including reductions in fitness or reproductive capacity, increased mortality from predation, low oxygen, and often toxic hydrogen sulfide in anoxic (i.e., no-oxygen) bottom waters. Many mobile organisms (i.e., fish, shrimp, and crabs) will move from hypoxic zones as oxygen falls. However, blue crabs in crab traps will die if covered with low-oxygen waters because the hypoxic area moves shoreward with tidal cycles. Studies of the reproductive capacity of Atlantic croaker suggest that severe reproductive impairment can occur over large coastal regions when marine fish populations are exposed to seasonal hypoxia (Thomas and Rahman 2010, 2012). Other mobile demersal (living on or near the bottom) organisms, such as eels, smaller swimming crabs, and rock shrimp, often swim closer to the surface when the lower part of the water column is hypoxic, which exposes them to increased predation. Benthic organisms (those entirely confined to the sea bottom) begin to demonstrate visible stress, and eventually die, when oxygen concentration falls low enough for long enough. The benthic communities in seasonally severe hypoxic areas are less diverse, less abundant, and contain less biomass than other benthic habitats with well-oxygenated waters. This means that the food resources available to bottom-feeding fishes and crustaceans are limited during and after hypoxia (Baustian, Craig, and Rabalais 2009).

The impact of hypoxic conditions on the harvest rates of important commercial and recreational fisheries is not always clear (Baustian et al. 2009); this is further complicated by the fact that many fisheries have experienced heavy fishing pressure at the same time that hypoxic zones have been growing, which makes it difficult to identify the primary cause of the decline in 
harvest rates (Breitburg et al. 2009a). While nutrient loadings can increase fishery production and yield up to the point where seasonal hypoxic and anoxic zones develop (Caddy 1993), they also increase the landings of less valuable pelagic fish relative to the landings of more valuable bottom-dwelling fish and shellfish (Caddy 1993; Chesney and Baltz 2001; Turner 2001; Turner et al. 1998). Further, what may appear to be beneficial effects of eutrophication may only occur in the short term, with potentially negative impacts on productivity or ecosystem function occurring in the longer term.

To illustrate the complexities and challenges of identifying the effects of these nutrient externalities, let's consider the effect of hypoxia on commercial near-shore shrimp along the Louisiana shelf in the NGOM. The presence, severity, and extent of the hypoxic zone peaks in this area between June and mid-August. White shrimp (Litopenaeus setiferus) spawn in this habitat during this time. Thus one would expect that the hypoxia would have a direct detrimental effect on the population of white shrimp. However, neither Zimmerman and Nance (2001) nor O'Connor and Whitall (2007) detected a loss of yield for this species. This may be because white shrimp inhabit shallower coastal and estuarine waters that are away from the hypoxic area. However, hypoxia has been found to affect brown shrimp (Farfantepenaeus aztecus) in an indirect way (Craig et al. 2005; Craig 2012). These shrimp spawn in deeper offshore waters. The postlarval brown shrimp migrate into wetland nursery habitat in late winter and spring when hypoxia is not usually present and then emigrate offshore as juveniles during the period of severe hypoxia on the shelf. Hypoxia likely blocks the movement of juvenile brown shrimp into offshore waters, and trawling fishermen can easily capture them in near-shore waters. As a result, these juvenile smaller shrimp are not able to grow and generate a greater secondary production in the offshore waters. This suggests that the main effect of hypoxia is not mortality but loss of future production. ${ }^{6}$

\section{Welfare Effects of Hypoxia on Fisheries and Ecosystem Services}

Economists have examined the effects of nutrient overenrichment on both marketed goods (primarily commercial fisheries) and nonmarket goods (primarily recreational fisheries). Although many aquatic ecosystem services have yet to receive attention, the existing literature provides valuable insights into some of the economic impacts of nutrient overenrichment and highlights the challenges of assessing welfare losses from eutrophication and hypoxia. The remainder of this section provides an overview of this literature.

\section{Welfare effects in the Baltic Sea}

There are at least two studies that consider the economic benefits of reducing nitrogen loading and hypoxic conditions in the Baltic Sea. Turner et al. (1999) describe the multiple market and policy failures contributing to eutrophication problems in the Baltic Sea including air and water pollution externalities, groundwater depletion, overfishing, poor land use policies, and market price interventions. They use stated preference studies to estimate the benefits associated with reduced nitrogen concentrations and conclude that the total economic benefit of reducing eutrophication levels in the Baltic is 70 billion Swedish kroners per year (or about $\$ 10$ billion).

${ }^{6}$ Brown shrimp are also more readily affected by low dissolved oxygen than white shrimp (see O'Connor and Whitall 2007; Zimmerman and Nance 2001). 
Although Turner et al. (1999) emphasize that this estimate is uncertain, its sheer magnitude suggests the possibility of large benefits.

Gren (2001) uses the Turner et al. (1999) estimates to evaluate the benefits and costs of four different policies to reduce nitrogen loading into the Baltic, based on the degree to which the nitrogen-contributing nations coordinate their actions. In addition to providing information on the distribution of benefits across affected countries, Gren's findings indicate the importance of coordinated actions in maximizing net benefits.

\section{Welfare effects in North Carolina}

Huang, Smith, and Craig (2010) estimated economic losses from hypoxia in the Neuse River and Pamlico Sound estuary in North Carolina, and they found that hypoxia accounted for about 13 percent of the decline in brown shrimp landings in the early 2000s. ${ }^{7}$ Using a bioeconomic model, Huang and Smith (2011) also find that the optimal harvest for brown shrimp occurs earlier when there is hypoxia. By combining the harvest functions with a model describing shrimpers' behavior and demand for shrimp, Huang et al. (2012) were able to examine the producer and consumer surplus losses from hypoxia. Given this fishery's small market share, they found that all losses accrue to producers.

In a study of the blue crab fishery in North Carolina, Smith (2007) evaluated losses from hypoxia using a bioeconomic model that incorporates the main behavioral and biophysical components required to capture the key dynamics in the ecosystem including the relationship between hypoxia and population dynamics, spatial factors (where hypoxic conditions occur in one patch but not in another), and the importance that the management regime plays (i.e., open access versus limits on harvest efforts). He found that the total benefits from reduced hypoxic conditions are not large, ranging from $\$ 1$ million to $\$ 7$ million annually. He also found, however, that the size of those benefits depends on the management regime.

\section{Welfare effects in the Chesapeake Bay}

Massey, Newbold, and Gentner (2006) linked a bioeconomic model of Atlantic flounder to a recreation demand model to evaluate the welfare effects of changes in oxygen concentrations in the Chesapeake Bay. Their analysis incorporated both the short-run effects on species crowding and abundance and the long-run population impacts associated with reduced survival and reproduction. They estimated that a 25 percent increase in dissolved oxygen levels across the entire region would cause catch rates to increase by about 20 percent, resulting in annual benefits that exceed $\$ 80$ million.

Lipton and Hicks (2003) studied the effect of low dissolved oxygen on the striped bass fishery in the Chesapeake Bay and evaluated the welfare effects associated with the degrading water quality in recreational fishing sites along the Patuxent River. Although their results suggest relatively small welfare effects due to the ability of anglers to easily switch to recreation sites elsewhere, they note that prolonged levels of anoxic conditions would result in annual angler losses of nearly $\$ 300,000$, even for this relatively small area. The authors note that their estimates do not include reproduction effects and therefore the health of the population in the long run.

${ }^{7}$ These results are consistent with the impacts on brown shrimp in the NGOM. 
Mistiaen, Strand, and Lipton (2003) examined the short-run potential impacts of low oxygen on the blue crab fishery in three tributaries of the Chesapeake Bay and found evidence that these conditions lower harvest rates for a given amount of effort. Simulations suggest that a 30 percent reduction in dissolved oxygen would lead to a short-run reduction in profits of more than $\$ 225,000$ for crabbers in the Patuxent River.

\section{Welfare effects in the Gulf of Mexico}

Less effort has been devoted to economic studies of the effects of hypoxia in the Gulf of Mexico, likely due to a lack of clear evidence that major commercial and recreational fisheries have been severely impacted. However, Jenkins et al. (2010) evaluated the benefits of wetland restoration along the southern portion of the Mississippi River corridor. Among other benefits, restoration of these wetlands would help reduce the amount of nitrates entering the river and, ultimately, reaching the Gulf of Mexico. They estimated the value of nitrogen mitigation from wetlands restoration in the region to be between $\$ 900$ and $\$ 1,900$ per hectare of land considered. ${ }^{8}$

As this discussion indicates, there have been only a few studies of the welfare losses associated with increased hypoxic conditions, and much remains unknown about both the biophysical impacts and the economic damages. Ecologists still do not fully understand the short-term and long-term consequences of sustained hypoxia on the health of ecosystems and individual species, and economists have only just begun to consider the economic consequences for commercial and recreational users. Notably absent from the literature are studies that address lost nonuse or existence values associated with hypoxic conditions and eutrophication.

\section{Policy Responses and Challenges to Cost-Effective Solutions}

A review of the literature on policy responses to hypoxic conditions identifies several common challenges (Elofsson, Folmer, and Gren 2003). In this section, we describe and assess the research on alternative policy options to reduce hypoxic zones in a cost-effective manner. Because each hypoxic zone and its watershed has unique physical, economic, and political characteristics, it is important to examine the policy options that are appropriate to the specific setting. We focus our discussion on two of the largest and most carefully studied hypoxic zones: the Baltic Sea and the NGOM (the world's largest and second largest hypoxic areas, respectively). First we briefly describe the policy setting in these two zones. Then we discuss some of the general research and policy challenges of addressing anthropogenically created hypoxia including the role of diffuse pollution sources, identifying cost-effective abatement strategies, interjurisdictional issues, interactions with other policies, the need for bioeconomic modeling, temporal issues, and the role of uncertainty.

\section{The Northern Gulf of Mexico Policy Setting}

The 2001 Action Plan for Reducing, Mitigating, and Controlling Hypoxia in the Northern Gulf of Mexico (Mississippi River/Gulf of Mexico Watershed Nutrient Task Force 2001), a joint federal and state effort, called for reducing the size of the NGOM hypoxic area to less than

${ }^{8}$ However, these estimates are based on benefit transfer methods, which may not accurately reflect damages in the Gulf. 
$5,000 \mathrm{~km}^{2}$ over a five-year period (ending in 2015) through voluntary actions, incentives, and education. In a more recent effort, in 2007 the U.S. Environmental Protection Agency (EPA) Science Advisory Board (SAB) convened a Hypoxia Assessment Panel (HAP) that reviewed the science background and newer information on nutrient loads and sources, and conducted a more detailed analysis of agricultural practices and economics in the Mississippi River watershed (SAB 2007) than the previous assessment. Parallel to this effort, the Task Force revised its Action Plan, which was completed in 2008 (Mississippi River/Gulf of Mexico Watershed Nutrient Task Force. 2008).

\section{The Baltic Sea Policy Setting}

The Baltic eutrophication problem has been on the European Union policy radar since the early 1970s, starting with the creation of the Helsinki Commission (HELCOM) in 1974. Two rounds of ministry-level agreements on nutrient load targets followed in 1988 and 2007. The 2007 plan, called the HELCOM Baltic Sea Action Plan (BSAP), calls for nutrient mitigation measures to be implemented by the Baltic coastline countries by 2021 , and, unlike the NGOM Action Plan, involves country-specific nutrient (nitrogen and phosphorus) abatement targets (Elofsson 2010).

\section{Importance of Nonpoint Sources of Pollution}

Pollution originating from nonpoint sources such as agriculture and urban areas is clearly central to the eutrophication issue. For example, Ribaudo et al. (2008) estimate that nonpoint sources contribute over 90 percent of the nitrogen in two-thirds of all nitrogen-impaired watersheds in the United States. Thus, without major reductions from nonpoint sources, the maximum achievable nitrogen reduction is below 10 percent. There is a large body of both theoretical and empirical research devoted to nonpoint source pollution control. ${ }^{9}$ To date, most of the empirical studies of nutrient reductions from nonpoint sources have been relatively small scale, generally due to the extensive data required to capture both the pollution processes and the behavior of individual economic agents. However, there have been advances in modeling and data availability that are starting to make studies of larger scale eutrophication problems due to nonpoint sources more feasible (e.g., Rabotyagov et al. 2010a).

\section{Cost-Effective Abatement across Regions and Industries}

Economic studies of large-scale eutrophication problems (e.g., Johnsen 1993; Paaby et al. 1996) use a modeling approach that focuses on the optimal allocation of abatement effort across sectors (e.g., between agriculture and the wastewater treatment sector). Utilizing this modeling approach, Ing-Marie Gren et al. have produced an important body of work related to the entire Baltic Sea basin. In the first in a series of published papers, Gren, Elofsson, and Jannke (1997) studied cost-efficient reductions in both nitrogen and phosphorus in order to reach HELCOM's 1993 target of a 50 percent reduction in nutrients in the Baltic Sea. Using an aggregated sectoral approach, but modeling the full set of nutrient delivery

\footnotetext{
${ }^{9}$ See Russell and Clark (2006), Shortle and Horan (2008), and Xepapadeas (2011) for excellent reviews.
} 
pathways to the sea, ${ }^{10}$ Gren et al. (1997) found very large cost savings when nutrient abatement responsibility is optimally allocated among sectors in nine affected countries relative to when proportional reductions are mandated. Several studies of the Baltic have subsequently been conducted using a similar approach (reviewed in Elofsson 2010). Ribaudo, Heimlich and Peters (2005) addressed the issue of cost-effective abatement allocation to address NGOM hypoxia. Like Rabotyagov et al. (2010a), they find large cost-efficiency gains from targeted abatement.

\section{International and Interjurisdictional Issues}

Because it is bordered by watersheds located in several countries, and thus involves multiple jurisdictions, the Baltic Sea offers a case study of how the issues of international cooperation, transboundary pollution, and managing the commons can affect the management of eutrophication problems (see, e.g., Folmer and de Zeeuw 2000). Unilateral policies generally result in too much eutrophication. Interestingly, in the case of the Baltic Sea, nitrogen and phosphorus act as limiting nutrients in different marine basins (at different times), which means that each nation's focus on its limiting nutrient may produce the externality of exporting its nonlimiting nutrient to the other country's basin (Turner et al. 1999). This externality can result in a reduction in total nutrients that is inadequate for achieving the targeted reductions in the hypoxic zone. In the case of the NGOM, the interactions between upstream and downstream states and their interactions with federal agencies are the most salient for finding solutions. Because the export of one state's nutrients to other states' waterways does not cause it any damage, individual states generally have no incentive to enact policies that are efficient from an overall societal perspective. Thus the transboundary nature of the nutrient export externality poses a serious challenge to the design of efficient policy, since governments will consider only those impacts that affect their own citizens and ignore impacts that affect those living downstream.

\section{Interactions with Other Policies and Environmental Issues}

Another challenge to designing cost-effective policy is that there are a host of existing policies that affect the incentives for actions that contribute to nutrient eutrophication problems. For example, the burning of fossil fuels directly and indirectly affects the amount of nitrogen deposited in marine systems, and future climate change impacts and mitigation/adaptation policies will likely affect the eutrophication problem. In the NGOM, climate change is likely to increase nutrient loads in rivers (Donner and Scavia 2007; Justić, Turner, and Rabalais 2003). Agricultural policies interact directly with eutrophication problems because agriculture is often the most important source of nutrient contributions. The share of agriculture's contribution varies depending on the particular ecosystem. For example, agriculture contributes over 70 percent of total nitrogen and phosphorus in the NGOM (Alexander et al. 2008), while agriculture contributes about a fifth of the total nitrogen load and a third of the total phosphorus load in the Baltic (Turner et al. 1999). The European Union's agricultural reform has been found to reduce nutrient loads in the Baltic (Schmid, Sinabell, and Hofreither 2007), but some policy changes shift pollution from agriculture to other sources (Brady 2003). In the United States, government support for agricultural conservation practices,

${ }^{10}$ This includes both water pathways (agriculture, urban sources) and atmospheric deposition from transportation and energy. 
while not directly aimed at NGOM hypoxia, has been estimated to reduce nutrient loadings significantly (USDA-NRCS 2012).

Nutrients often impair upstream rivers, lakes, and streams. Upstream policies dealing with local pollution are generally not coordinated with efforts to abate downstream eutrophication effects. For example, as part of its efforts to address the problem of nitrate pollution of drinking water, the US city of Des Moines, Iowa, operates the world's largest denitrification facility (Jha, Gassman, and Arnold 2007), which releases the nitrogen that has been removed from the drinking water further downstream. It is also important to account for the upstream benefits of nutrient load reductions (e.g., improved recreational fisheries, healthier wildlife habitat) when evaluating marine eutrophication policies.

\section{Need for Bioeconomic Modeling on Land and Sea}

Large-scale studies of eutrophication and water pollution effects on coastal waters, which incorporate economic heterogeneity across countries, sectors, and abatement technologies, often lack the detailed spatial information necessary to identify cost-effective targeting of abatement across space. Many models operate on the scale of a country (Gren 2001) or large region (Ribaudo et al. 2005). For waterborne nutrients originating from agriculture, pollution fate and transport (the process by which nutrients and water move through the landscape) is critical, and thus the relevant spatial unit is that of a watershed. Furthermore, the level of watershed resolution and the level of resolution of various polluting entities within the watershed are fundamentally important for policy analysis, choice of economic instruments, and targeting of policies to specific locations. Additional bioeconomic modeling - the integrated modeling of both economic and biophysical processes-is needed to provide policymakers with the tools they require to understand how changes in policy can affect economic decision making, which in turn affects ecosystems.

This suggests that bioeconomic modeling on land should be a key component of any effort to address the eutrophication problem (the need for bioeconomic modeling of marine environments is clear). Agricultural and environmental economists have long incorporated biophysical models into economic modeling and policy analysis for water quality. ${ }^{11}$ However, only fairly recently have there been advances in modeling and computational capacity that allow for the use of bioeconomic models in larger-scale studies appropriate for evaluating policies aimed at reducing nutrient delivery to coastal ecosystems (e.g., Kling et al. 2006). A study by Rabotyagov et al. (2010a), which focuses on agriculture in the Upper Mississippi River basin, combined a spatial model with a biophysical process model to identify the optimal allocation of nutrient abatement efforts across subwatersheds. ${ }^{12}$ Although this study integrates a simple economic decision model with a biophysical watershed model at a relatively high spatial resolution, it is not linked to a model of the hypoxic zone. Polasky and Segerson (2009) discuss the broader opportunities and challenges of integrating ecological and economic models.

Bioeconomic analysis of nutrient movement at sea is important for cost-effective policy design, as well as being essential for evaluating welfare impacts. Gren (2009) uses the spatial

\footnotetext{
${ }^{11}$ See Braden et al. (1989) for an example in the context of sediment control.

${ }^{12}$ Their model examines fertilizer reductions, agricultural conservation practices, and land retirement as nutrient abatement technologies but, unlike Ribaudo et al. (2005), does not fully represent agricultural market interactions, and does not include other relevant technology such as wetlands (e.g., Gren et al. 1997).
} 
dynamics of eutrophication in the Baltic Sea (where nutrients deposited at one location move across various marine basins and contribute to eutrophication problems) to identify a better allocation of abatement efforts in the Baltic drainage basin.

These examples suggest that researchers have made progress in developing and applying bioeconomic models that consider many of the economic and physical characteristics and impacts of hypoxic zones. However, significantly more work is needed to improve the models' spatial resolution and the representation of a broader range of nutrient abatement options, as well as better modeling of feedbacks between components of the system.

\section{Temporal Dimension}

Time is an important factor to consider when examining the eutrophication process. For example, in the Baltic, the impact of nutrients, especially phosphorus, can be felt for decades (Gren 2009; Turner et al. 1999). Several studies have examined the effects of eutrophication in the Baltic using different temporal scales. Gren (2009) considers a sixty-year time horizon to identify a dynamic, spatially efficient allocation of nutrient abatement effort. Goetz and Zilberman (2000) develop a theoretical model of spatial dynamic nutrient control, where the problem is divided into two stages and the spatial solution is optimized over time. Hart (2003) models lengthy time lags that may occur due to upstream nitrogen accumulating in groundwater and considers the optimal allocation of upstream (agricultural) versus downstream (mussel cultivation) abatement.

Researchers have also investigated the issue of irreversibility, in terms of either abatement investment (e.g., investment in municipal wastewater treatment plants, as modeled by Laukkanen and Huhtala 2008) or ecosystem response thresholds (Mäler, Xepapadeas, and de Zeeuw 2003; Naevdal 2001), and have found that the results are highly sensitive to assumptions about the eutrophication process (e.g., how long it takes to restore an ecosystem to health once nutrient enrichment is stopped).

Issues concerning time lags, whether the eutrophication problem should be approached from a stock or flow pollution perspective, and whether there are thresholds (i.e., nutrient load levels beyond which fundamental changes to an ecosystem will occur) are empirical questions that require additional data and analysis and are important for the design of cost-effective and appropriate policies.

\section{Uncertainty}

Uncertainty is endemic to all water pollution processes, and nonpoint source emissions (and abatement) are inherently stochastic. A major reason for this is that weather, especially rainfall, is a key determinant of how and when water pollutants move across the landscape. This uncertainty can be important for policy design and targeting of locations for abatement because abatement approaches that work well under typical weather conditions may not be appropriate in the case of large rainfall events.

Nonpoint source abatement is generally viewed as more uncertain than abatement from point sources, which has led to a policy preference for point source abatement. However, as noted by Shortle and Horan (2008), the social planner may actually want to target the more variable nonpoint sources because this can be expected to reduce overall pollution damage uncertainty. Other authors (e.g., Byström, Andersson, and Gren 2000; Gren, Destouni, and 
Tempone 2002; Gren 2010) have noted that when abatement measures are uncertain but their distributions are known, probabilistic constraints can be specified and transformed into deterministic equivalents that can be optimized using methods like chance-constrained programming (Charnes and Cooper 1963). Rabotyagov, Jha, and Campbell (2010b) used a similar approach to identify cost-effective combinations of nutrient-reducing practices resilient to weather shocks. One important caveat is that these approaches can deal with quantifiable uncertainty (risk) but not the uncertainty that stems from a fundamental lack of understanding of ecosystem processes.

In summary, coastal eutrophication and hypoxic zones create a number of unique challenges for policy design. For example, the scale and scope of coastal eutrophication problems makes coordinated policy response challenging, especially because large drainage basins (often dominated by agriculture, industry, and urban areas) are frequently the main culprit. Moreover, multiple pollutants, originating from a variety of (both point and nonpoint) sources in multiple political jurisdictions, and multiple possible abatement technologies are involved. Finally, the transport and fate of multiple pollutants is difficult to characterize, requires significant data and modeling efforts, and is inherently stochastic. The issue of eutrophication and its control is further complicated by its dependence on pollution deposition from outside the watershed and the upstream impacts of pollutants. Depending on the pollution control policy, general equilibrium effects may be important when a large area contributes to eutrophication. In addition, data needed for modeling physical processes are usually not well matched to the economic data on production or abatement activities. Economists can help guide policymakers in designing cost-effective policies by recognizing these challenges and integrating them into their research and policy recommendations.

\section{Modeling the Relationship between Pollutants and the Size of the NGOM Hypoxic Zone}

Ecological theory suggests that the extent of eutrophication should be a function of nutrient inputs. However, statistical evidence on multiple nutrients contributing to the size of hypoxia has been sparse. This section further explores the impact of nutrients on hypoxia through a statistical model that estimates the relationship between pollutants (nutrients) and the size (bottom area) of the NGOM hypoxic zone.

The debate about the factors responsible for the severity of the NGOM hypoxic zone goes back as far as Wiseman et al. (1997), who first observed a relationship between Mississippi streamflow and the area of hypoxia. We contribute to this debate by estimating a production function relationship for the hypoxic zone that suggests that all macronutrients-nitrogen $(\mathrm{N})$, phosphorus $(\mathrm{P})$, and silicate $(\mathrm{Si}$ ) — explain the extent of hypoxia and that lags in the impacts of nutrients are important. Such "ecosystem memory" relationships (Turner, Rabalais, and Justic 2006) have long been suggested by researchers but until now have not been corroborated statistically.

Most of the existing hypoxia models of the NGOM focus on $\mathrm{N}^{13}$ However, $\mathrm{N}$ is not the only limiting factor in phytoplankton growth (Turner and Rabalais 2013). Moreover, the dynamics of the NGOM's coastal systems result in some portions of the zone being $\mathrm{N}$ limited

\footnotetext{
${ }^{13}$ For a more detailed discussion of existing NGOM hypoxia models, see the online supplemental materials.
} 


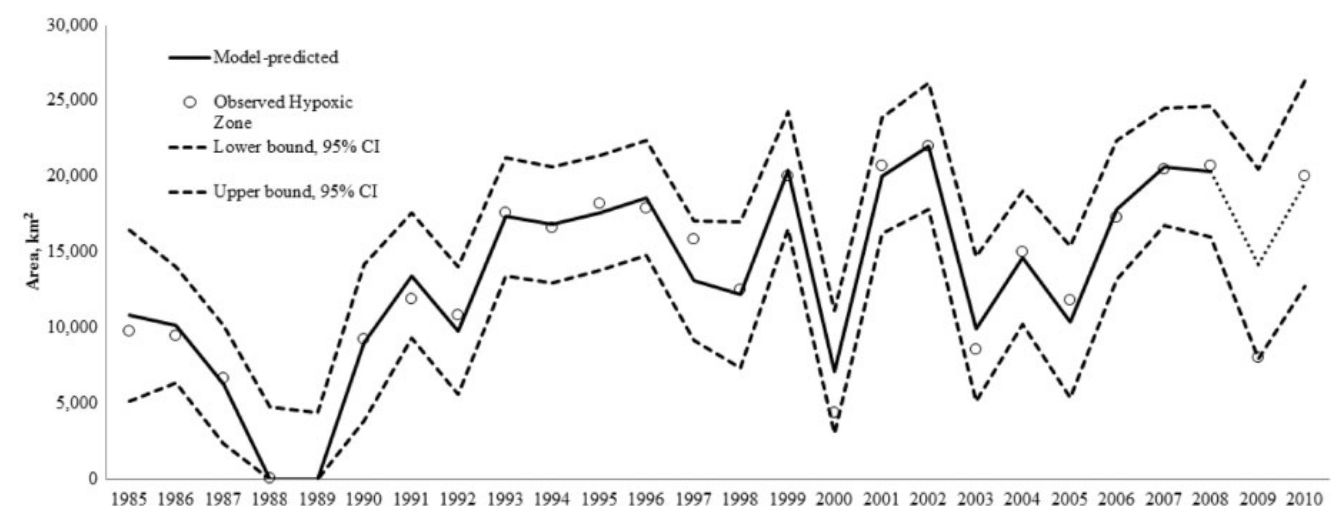

Figure 3 Model results: Observed and estimated area of Gulf of Mexico hypoxia (2009 and 2010 used for prediction)

while others are P limited (Quigg et al. 2011; Turner and Rabalais 2013). As a result, a simple production function is not likely to describe accurately the underlying production process for the total size of the hypoxic zone. ${ }^{14}$

\section{NGOM Hypoxia Model}

We estimate the area of the hypoxic zone using a production function that accounts for the possibility of multiyear lags, the importance of multiple nutrients $(\mathrm{N}, \mathrm{P}, \mathrm{Si})$, and the time series nature of the data. ${ }^{15}$ We estimate the model using hypoxia size measurements from 1985 to 2008 and assess the model's performance using data for 2009 and 2010 (see Figure 3). ${ }^{16}$

The model suggests that spring nutrient (N, P, Si) loadings and other factors (hurricanes, currents, wind conditions, and sea temperature anomalies) affect the size of the NGOM hypoxic area. ${ }^{17}$ While all nutrients are found to positively affect hypoxia size, both $\mathrm{N}$ and $\mathrm{P}$ have a persistent impact on hypoxia (that diminishes over time), with the impact being significant up to five years into the future. This is consistent with the "ecosystem memory" literature referred to earlier, although the time dimension was found to be less important than what has been suggested for the Baltic Sea case, as river nutrient loadings older than five years were not found to significantly affect the size of the NGOM hypoxia. Clearly, the duration of nutrient impacts can have important implications for policy and for the decision about whether to pursue dynamic approaches in economic and policy analyses.

The results also confirm the importance of factors other than nutrients. ${ }^{18}$ Hurricanes are a major disturbance, and we find that they may affect current and future hypoxia formation

${ }^{14}$ If the entire process were characterized by a simple Leontief-type production function, then abatement would need to focus on a single nutrient (Kuosmanen and Laukkanen 2011). However, when areas of different input limitation are present, the observable "hypoxia production function" will appear to exhibit substitution between N, P, Si, and other limiting inputs (e.g., light).

${ }^{15}$ More specifically, we estimate a translog production function with three inputs (N, P, Si), allowing for lags in responses and serially correlated errors.

${ }^{16}$ Data were not available for 1989. Data for 2011-2013 were not included because the weather variables computed by Forrest, Hetland, and DiMarco (2012) only extend through 2010.

${ }^{17}$ The detailed regression results and statistics are presented in Appendix Table 1.

${ }^{18} \mathrm{We}$ controlled for the effects of hurricanes, wind power, currents, and surface temperature anomalies. 


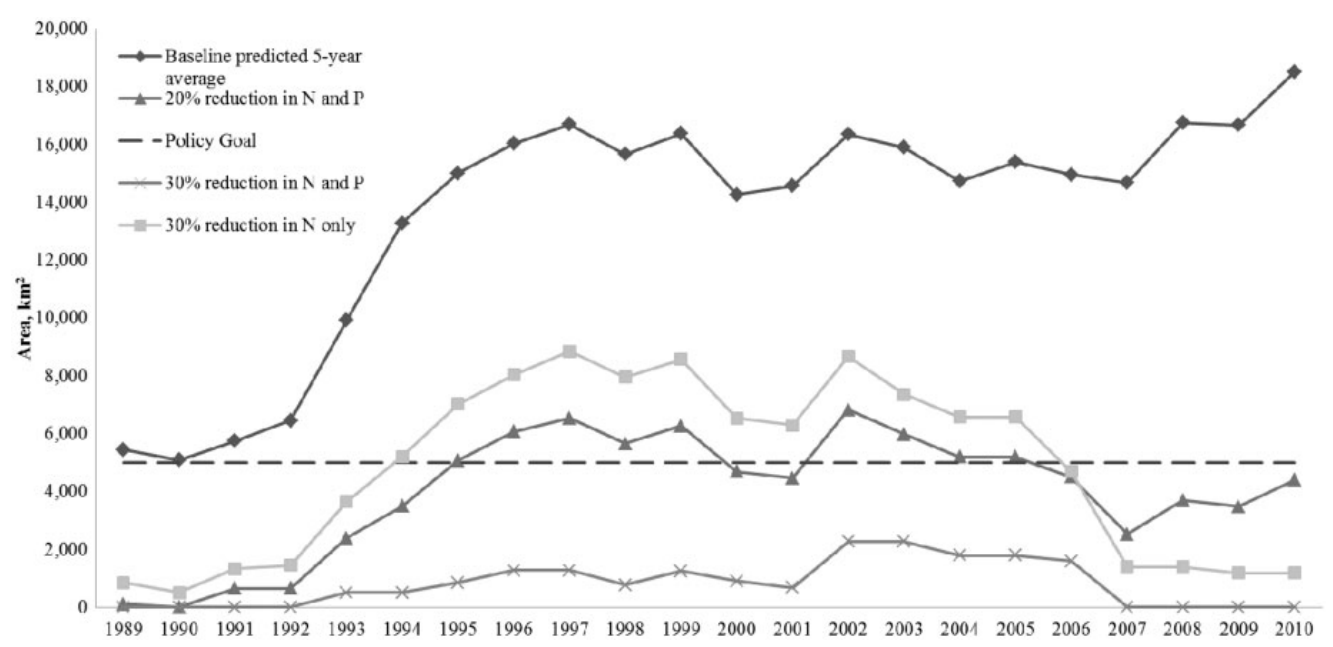

Figure 4 Observed and counterfactual scenarios of five-year average extent of Gulf of Mexico hypoxia

in complicated ways. While hurricanes temporarily reduce the size of current hypoxia by mixing the water column, we also find that the impact of the current year's nutrients is affected by the presence of a hurricane. The presence of unusual currents has a negative impact on the size of the hypoxic zone. We find a positive relationship between hypoxia size and wind power, corroborating the theoretical conjecture of Kemp et al. (2009). ${ }^{19}$ An anomaly in sea temperature, first explored by Forrest et al. (2012), was found to be significant at the 10 percent level, which further suggests the importance of weather and that the changing climate may have an important influence on the size of the hypoxic zone.

\section{Implications for Policy Goals Addressing the NGOM Hypoxia}

The Action Plan for Reducing, Mitigating, and Controlling Hypoxia in the NGOM recommends a dual $\mathrm{N}$ and $\mathrm{P}$ reduction strategy, focusing on agricultural sources in the watershed. As noted earlier, the policy goal is to reduce the size of the NGOM hypoxia to $5,000 \mathrm{~km}^{2}$ or less (as a five-year average). The 2001 Action Plan estimated that a 30 percent reduction in the $\mathrm{N}$ load would likely be needed to achieve that goal. It was later predicted that $\mathrm{N}$ load reductions closer to 35 to 45 percent would be needed (Justić et al. 2003; Scavia et al. 2003). Using our estimated model, we examine the implications of reducing the observed $\mathrm{N}$ and $\mathrm{P}$ loads for achieving the Action Plan goal (see Figure 4).

We find that a simultaneous 30 percent reduction in May $\mathrm{N}$ and June P loads relative to baseline annual loads would have been sufficient to reduce the size of the hypoxia to less than $5,000 \mathrm{~km}^{2}$. We find that a 30 percent reduction in $\mathrm{N}$ alone would not have been sufficient to reach the goal, which is consistent with the recent scientific consensus (Justić et al. 2003; Scavia et al. 2003).

${ }^{19}$ Winds can also potentially shift the river plume and hence the zone where hypoxia may develop (Forrest et al., 2012). 


\section{Conclusions and Research Needs}

Eutrophication and its associated dead zones are global problems that are increasing at an alarming rate in both size and duration. To increase understanding of the linkages between nutrient enrichment and dead zones, we have presented estimates from an ecologically informed hypoxia production function for the NGOM and assessed the nutrient reductions likely needed to meet the policy goals for the NGOM. Although far from the last word on the relationship between nutrients and the size of the dead zone, our analysis and results provide new insights into the contribution of multiple nutrients and the importance of time lags.

In order to design effective and efficient policies to mitigate eutrophication and the size and extent of hypoxic zones, a number of issues and challenges must be addressed, including improving the integration of ecological and economic models, recognizing spatial interdependencies, considering the dynamics of pollution and economic processes, improving our understanding of the nonuse values of lost ecosystem services, and explicitly accounting for uncertainty, policy interactions, and issues of political economy. This suggests that economists must work closely with terrestrial and marine ecologists and other natural scientists. One specific area where integrated work is needed is in the bioeconomic modeling of terrestrial ecosystems, including agricultural and urban areas, which would complement the continuing bioeconomic modeling of aquatic ecosystems. All such work should examine the effects of nutrient overenrichment on species that are not commercially important but are aesthetically enjoyable, provide significant existence values, or are key to overall ecosystem stability (Barbier 2012).

We close with an observation about another area where integration is urgently neededconnecting the findings from integrated economic and ecological models and ecosystem valuation work to the policy process. To date, such integration has been sorely lacking. For example, despite the numerous rigorous studies of hypoxia in the Baltic Sea, there has been little serious attention in the policy arena to identifying and implementing cost-effective nutrient abatement. To create these linkages, economists need to do a better job of communicating to policymakers that the efficiency properties they study contribute to the well-being of humans and the environment.

Appendix Table I Coefficient estimates for the Gulf of Mexico "hypoxia production function"

\begin{tabular}{llcrrr}
\hline Parameter & Description & Estimate & SE & t value & $\boldsymbol{P}$ value \\
\hline$\beta_{\text {intercept }}$ & Intercept & -515666 & 37342 & -13.81 & $<0.000$ I \\
$\beta_{\text {hurricane }}$ & Hurricane dummy & -321514 & 38944 & -8.26 & $<0.000$ I \\
$\beta_{\text {current }}$ & Currents dummy & -5653 & 1925 & -2.94 & 0.0149 \\
$\beta_{\text {hurr } N}$ & Hurricane-N interaction & 120202 & 11690 & 10.28 & $<0.000$ I \\
$\beta_{\text {hurr } P}$ & Hurricane-P interaction & -69618 & 7723 & -9.01 & $<0.000$ I \\
$\beta_{0, N}$ & N load, current year & 14702 & 2997 & 4.91 & 0.0006 \\
$\beta_{1, N}$ & N load, I-year lag & 12262 & 2409 & 5.09 & 0.0005 \\
$\beta_{2, N}$ & N load, 2-year lag & 9822.70 & 1869 & 5.26 & 0.0004 \\
$\beta_{3, N}$ & N load, 3-year lag & 7383.30 & 1429 & 5.17 & 0.0004 \\
$\beta_{4, N}$ & N load, 4-year lag & 4943.90 & 1206 & 4.10 & 0.0022 \\
$\beta_{5, N}$ & N load, 5-year lag & 2504.50 & 1315 & 1.90 & 0.086 I \\
$\beta_{0, P}$ & P load, current year & 19796 & 2175 & 9.10 & $<0.000$ I \\
\hline
\end{tabular}


Appendix Table I Continued

\begin{tabular}{llcrrr}
\hline Parameter & Description & Estimate & SE & t value & $\boldsymbol{P}$ value \\
\hline$\beta_{1, P}$ & P load, I-year lag & 15523 & 1525 & 10.18 & $<0.0001$ \\
$\beta_{2, P}$ & P load, 2-year lag & 11249 & 1122 & 10.02 & $<0.0001$ \\
$\beta_{3, P}$ & P load, 3-year lag & 6975.86 & 1238 & 5.63 & 0.0002 \\
$\beta_{4, P}$ & P load, 4-year lag & 2702.38 & 1773 & 1.52 & 0.1585 \\
$\beta_{5, P}$ & P load, 5-year lag & -1571.09 & 2469 & -0.64 & 0.5389 \\
$\beta_{\text {Si }}$ & Si load, current year & 9435 & 3534 & 2.67 & 0.0235 \\
$\beta_{\text {windpower }}$ & Wind power & 35.04 & 6.16 & 5.69 & 0.0002 \\
$\beta_{\text {SeaTemp }}$ & Sea surface temperature anomaly & -3766 & 1922 & -1.96 & 0.0786 \\
$\theta$ & Autoregressive order-I parameter & 0.74 & 0.21 & 3.53 & 0.0055 \\
\hline
\end{tabular}

Number of observations: 23.

Degrees of freedom, error 10.

Total $R^{2}: 0.9662$.

Log-likelihood: - 193.28I85.

Bayesian information criterion: 427.33 .

\section{References}

Alexander, R., R. Smith, G. Schwarz, E. Boyer, J. Nolan, and J. Brakebill. 2008. Differences in phosphorus and nitrogen delivery to the Gulf of Mexico from the Mississippi River Basin.

Environmental Science and Technology 42: 822-30.

Barbier, E. B. 2012. Progress and challenges in valuing coastal and marine ecosystem services. Review of Environmental Economics and Policy 6: 1-19.

Battaglini, E., B. Plonka, and A. Merla. 2008. Europe and Central Asia Region. World Bank Environment Matters. http://go.worldbank.org/ 83RJ1ZP660: 32-34 (accessed December 1, 2013).

Baustian, M. M., J. K. Craig, and N. N. Rabalais. 2009. Effects of summer 2003 hypoxia on macrobenthos and Atlantic croaker foraging selectivity in the northern Gulf of Mexico. Journal of Experimental Marine Biology and Ecology 381: S31-S37.

Braden, J. B., G. V. Johnson, A. Bouzaher, and D. Miltz. 1989. Optimal spatial management of agricultural pollution. American Journal of Agricultural Economics 71: 404-13.

Brady, M. 2003. The relative cost-efficiency of arable nitrogen management in Sweden. Ecological Economics 47: 53-70.

Breitburg, D. L., J. K. Craig, R. S. Fulford, K. A. Rose, W. R. Boynton, D. C. Brady, B. J. Ciotti, R. J. Diaz, K. D. Friedland, J. D. Hagy III, D. R. Hart, A. H. Hines, E. D. Houde, S. E. Kolesar, S. W. Nixon,
J. A. Rice, D. H. Secor, and T. E. Targett. 2009a. Nutrient enrichment and fisheries exploitation: Interactive effects on estuarine living resources and their management. Hydrobiologia 629: 31-47.

Breitburg, D. L., D. W. Hondorp, L. A. Davias, and R. J. Diaz. 2009b. Hypoxia, nitrogen, and fisheries: Integrating effects across local and global landscapes. Annual Review of Marine Science 1: 329-49. Byström, O., H. Andersson, and I.-M. Gren. 2000. Economic criteria for restoration of wetlands under uncertainty. Ecological Economics 35: 35-45.

Caddy, J. F. 1993. Towards a comparative evaluation of human impacts on fishery ecosystems of enclosed and semi-enclosed seas. Reviews in Fisheries Science 1: 57-95.

$$
\text { 2001. A brief overview of marine }
$$
catchment basin effects on marine fisheries. In Coastal hypoxia: Consequences for living resources and ecosystems, ed. N. N. Rabalais, and R. E. Turner. Washington, DC: Coastal and Estuarine Studies 58, American Geophysical Union.

Charnes, A., and W. W. Cooper. 1963.

Deterministic equivalents for optimizing and satisfying under chance constraints. Operations Research 11: 18-39.

Chesney, E. J., and D. M. Baltz. 2001. The effects of hypoxia on the northern Gulf of Mexico coastal 
ecosystem: A fisheries perspective. In Coastal hypoxia: Consequences for living resources and ecosystems, ed. N. N. Rabalais, and R. E. Turner. Washington, DC: Coastal and Estuarine Studies 58, American Geophysical Union.

Conley, D. J., J. Carstensen, J. Aigars, P. Axe, E. Bonsdorff, T. Eremina, B.-M. Haahti, C. Humborg, P. Jonsson, J. Kotta, C. Lännegren, U. Larsson, A. Maximov, M. R. Medina, E. Lysiak-Pastuszak, N. Remeikaitè-Nikienè, J. Walve, S. Wilhelms, and L. Zillén. 2011. Hypoxia is increasing in the coastal zone of the Baltic Sea. Environmental Science and Technology 45: 6777-83.

Conley, D. J., H. W. Paerl, R. W. Howarth, D. F. Boesch, S. P. Seitzinger, K. Havens, C. Lancelot, and G. E. Likens. 2009. Ecology. Controlling eutrophication: Nitrogen and phosphorus. Science 323: 1014-15.

Craig, J. K. 2012. Aggregation on the edge: Effects of hypoxia avoidance on the spatial distribution of brown shrimp and demersal fishes in the Northern Gulf of Mexico. Marine Ecology-Progress Series 445: 75-95.

Craig, J. K., L. B. Crowder, and T. A. Henwood. 2005. Spatial distribution of brown shrimp (Farfantepenaeus aztecus) on the northwestern Gulf of Mexico shelf: Effects of abundance and hypoxia. Canadian Journal of Fisheries and Aquatic Science 62: 1295-1308.

Diaz, R. J., and R. Rosenberg. 1995. Marine benthic hypoxia: A review of its ecological effects and the behavioural responses of benthic macrofauna. Oceanography and Marine Biology: An Annual Review 33: 245-303.

2008. Spreading dead zones and consequences for marine ecosystems. Science 321: 926-29.

Doney, S. C. 2010. The growing human footprint on coastal and open-ocean biogeochemistry. Science 328: 1512-16.

Donner, S. D., and D. Scavia. 2007. How climate controls the flux of nitrogen by the Mississippi River and the development of hypoxia in the Gulf of Mexico. Limnology and Oceanography 52: 856-61.

Elofsson, K. 2010. The costs of meeting the environmental objectives for the Baltic Sea: A review of the literature. Ambio 39: 49-58.
Elofsson, K., H. Folmer, and I.-M. Gren. 2003. Management of eutrophicated coastal ecosystems: A synopsis of the literature with emphasis on theory and methodology. Ecological Economics 47: $1-11$.

Folmer, H., and A. de Zeeuw. 2000. International environmental problems and policy. In Principles of Environmental and Resource Economics, ed. $\mathrm{H}$. Folmer, and H. L. Gabel. Cheltenham, UK: Edward Elgar.

Forrest, D. R., R. D. Hetland, and S. F. DiMarco. 2012. Corrigendum: Multivariable statistical regression models of the areal extent of hypoxia over the Texas-Louisiana continental shelf. Environmental Research Letters 7: 019501.

Goetz, R. U., and D. Zilberman. 2000. The dynamics of spatial pollution: The case of phosphorus runoff from agricultural land. Journal of Economic Dynamics and Control 24: 143-63.

Gren, I.-M. 2001. International versus national actions against nitrogen pollution of the Baltic Sea. Environmental and Resource Economics 20: 41-59. 2009. A numerical model for dynamic cost effective mitigation of eutrophication with spatial heterogeneity in the Baltic Sea. Working paper series/Swedish University of Agricultural Sciences, Department of Economics.

- 2010. Resilience value of constructed coastal wetlands for combating eutrophication. Ocean \& Coastal Management 53: 358-65.

Gren, I.-M., G. Destouni, and R. Tempone. 2002. Cost effective policies for alternative distributions of stochastic water pollution. Journal of Environmental Management 66: 145-57.

Gren, I.-M., K. Elofsson, and P. Jannke. 1997. Cost-effective nutrient reductions to the Baltic Sea. Environmental and Resource Economics 10: 341-62.

Hart, R. 2003. Dynamic pollution control—time lags and optimal restoration of marine ecosystems. Ecological Economics 47: 79-93.

Huang, L., L. A. B. Nichols, J. K. Craig, and M. D. Smith. 2012. Measuring welfare losses from hypoxia: The case of North Carolina brown shrimp. Marine Resource Economics 27: 3-23.

Huang, L., and M. D. Smith. 2011. Management of an annual fishery in the presence of ecological stress: The case of shrimp and hypoxia. Ecological Economics 70: 688-97. 
Huang, L., M. D. Smith, and J. K. Craig. 2010. Quantifying the economic effects of hypoxia on a fishery for brown shrimp (Farfantepenaeus aztecus). Marine and Coastal Fisheries: Dynamics, Management, and Ecosystem Science 2: 232-48. Jenkins, W. A., B. C. Murray, R. A. Kramer, and S. P. Faulkner. 2010. Valuing ecosystem services from wetlands restoration in the Mississippi alluvial valley. Ecological Economics 69: 1051-61. Jha, M., P. W. Gassman, and J. G. Arnold. 2007. Water quality modeling for the Raccoon River watershed using SWAT. Transactions of the ASABE 50: 479-93.

Johnsen, F. H. 1993. Economic analyses of measures to control phosphorus run-off from nonpoint agricultural sources. European Review of Agricultural Economics 20: 399-418.

Justić, D., R. E. Turner, and N. N. Rabalais. 2003. Climatic influences on riverine nitrate flux: Implications for coastal marine eutrophication and hypoxia. Estuaries 26: 1-11.

Kemp, W. M., J. M. Testa, D. J. Conley, D. Gilbert, and J. D. Hagy. 2009. Temporal responses of coastal hypoxia to nutrient loading and physical controls. Biogeosciences 6: 2985-3008.

Kling, C. L., S. Secchi, M. Jha, H. Feng, P. W. Gassman, and L. A. Kurkalova. 2006. Upper Mississippi River Basin modeling system part 3: Conservation practice scenario results. In Coastal hydrology and processes, ed. V. P. Singh, and Y. J.

Xu. Highland Ranch, CO: Water Resources Publications.

Kuosmanen, T., and M. Laukkanen. 2011. (In)efficient environmental policy with interacting pollutants. Environmental and Resource Economics 48: 629-49.

Laukkanen, M., and A. Huhtala. 2008. Optimal management of a eutrophied coastal ecosystem: balancing agricultural and municipal abatement measures. Environmental and Resource Economics 39: 139-59.

Levin, L. A., W. Ekau, A. J. Gooday, F. Jorissen, J. J. Middelburg, W. Naqvi, N. N. Rabalais, and J. Zhang. 2009. Effects of natural and human-induced hypoxia on coastal benthos. Biogeosciences 6: 2063-98.

Lipton, D., and R. Hicks. 2003. The cost of stress: Low dissolved oxygen and economic benefits of recreational striped bass (Morone saxatilis) fishing in the Patuxent River. Estuaries 26: 310-15.

Mäler, K.-G., A. Xepapadeas, and A. de Zeeuw. 2003. The economics of shallow lakes.

Environmental and Resource Economics 26: 603-24.

Massey, D. M., S. C. Newbold, and B. Gentner. 2006. Valuing water quality changes using a bioeconomic model of a coastal recreational fishery. Journal of Environmental Economics and Management 52: 482-500.

Mee, L. D., J. Friedrich, and M. T. Gomoiu. 2005. Restoring the Black Sea in times of uncertainty. Oceanography 18: 100-11.

Millennium Ecosystem Assessment. 2005.

Ecosystems and human well-being: Synthesis. Washington, DC: Island Press.

Mississippi River/Gulf of Mexico Watershed Nutrient Task Force. 2001. Action plan for reducing, mitigating, and controlling hypoxia in the northern Gulf of Mexico. Office of Wetlands, Oceans, and Watersheds, US Environmental Protection Agency, Washington, DC. . 2008. Gulf hypoxia action Plan 2008 for reducing, mitigating, and controlling hypoxia in the northern Gulf of Mexico and improving water quality in the Mississippi River basin. Office of Wetlands, Oceans, and Watersheds, US Environmental Protection Agency, Washington, DC.

Mistiaen, J. A., I. E. Strand, and D. Lipton. 2003. Effects of environmental stress on Blue Crab (Callinectes sapidus) harvests in Chesapeake Bay tributaries. Estuaries 26: 316-22.

Naevdal, E. 2001. Optimal regulation of eutrophying lakes, fjords and rivers in the presence of threshold effects. American Journal of Agricultural Economics 83: 972-84.

Nixon, S. W. 1995. Coastal marine eutrophication: A definition, social causes, and future concerns. Ophelia 41: 199-219.

O'Connor, T., and D. Whitall. 2007. Linking hypoxia to shrimp catch in the northern Gulf of Mexico. Marine Pollution Bulletin 54: 460-63.

Paaby, H., J. J. Jensen, P. Kristensen, F. Moller, and E. Skop. 1996. Reducing nutrient loadings to marine waters: A cost effectiveness analysis. In Modelling the Economy and the Environment, ed. 
B. Madsen, C. Jensen-Butler, J. B. Mortensen, A. M. Bruun, and A. M. Christensen. Berlin: Springer-Verlag.

Polasky, S., and K. Segerson. 2009. Integrating ecology and economics in the study of ecosystem services: Some lessons learned. Annual Review of Resource Economics 1: 409-34.

Quigg, A., J. B. Sylvan, A. B. Gustafson, T. R. Fisher, R. L. Oliver, S. Tozzi, and J. W.

Ammerman. 2011. Going west: Nutrient limitation of primary production in the northern Gulf of Mexico and the importance of the Atchafalaya River. Aquatic Geochemistry 17: 519-44.

Rabalais, N. N., R. J. Diaz, L. A. Levin, R. E. Turner, D. Gilbert, and J. Zhang. 2010. Dynamics and distribution of natural and human-caused hypoxia. Biogeosciences 7: 585-619.

Rabalais, N. N., and R. E. Turner, eds. 2001. Coastal hypoxia: Consequences for living resources and ecosystems. Coastal and Estuarine Studies 58. Washington, DC: American Geophysical Union.

Rabotyagov, S. S., T. Campbell, M. Jha, P. W. Gassman, J. Arnold, L. Kurkalova, S. Secchi, H. Feng, and C. L. Kling. 2010a. Least-cost control of agricultural nutrient contributions to the Gulf of Mexico hypoxic zone. Ecological Applications 20 (6): 1542-55.

Rabotyagov, S. S., M. Jha, and T. D. Campbell. 2010b. Nonpoint-source pollution reduction for an Iowa watershed: An application of evolutionary algorithms. Canadian Journal of Agricultural Economics/Revue Canadienne d'Agroéconomie 58: 411-31.

Ribaudo, M., L. Hansen, D. Hellerstein, and C. Greene. 2008. The use of markets to increase private investment in environmental stewardship. USDA-ERS Economic Research Report 64. http://www.ers.usda.gov/publications/err-economic-research-report/err64.aspx\#.Up49w8RDtyI (accessed December 1, 2013).

Ribaudo, M. O., R. Heimlich, and M. Peters. 2005. Nitrogen sources and Gulf hypoxia: Potential for environmental credit trading. Ecological Economics 52: 159-68.

Russell, C. S., and C. D. Clark. 2006. Economic instruments and nonpoint source water pollution. In Water Quality Management in the Americas, ed. K. Asit, C. Biswas, B. Tortajada, B. Braga, and D. Rodriguez. New York: Springer.
Savchuk, O., and F. Wulff. 2009. Long-term modeling of large-scale nutrient cycles in the entire Baltic Sea. Hydrobiologia 629: 209-24.

Scavia, D., N. N. Rabalais, R. E. Turner, D. Justić, and W. J. Wiseman. 2003. Predicting the response of Gulf of Mexico hypoxia to variations in Mississippi River nitrogen load. Limnology and Oceanography 48: 951-56.

Schmid, E., F. Sinabell, and M. F. Hofreither. 2007. Phasing out of environmentally harmful subsidies: Consequences of the 2003 CAP reform. Ecological Economics 60: 596-604.

Science Advisory Board (SAB). 2007. Hypoxia in the northern Gulf of Mexico. Washington, DC: U.S. Environmental Protection Agency.

Selman, M., S. Greenhalgh, R. Diaz, and Z. Sugg. 2008. Eutrophication and hypoxia in coastal areas: A global assessment of the state of knowledge. WRI Policy Note, World Resources Institute.

Shortle, J. S., and R. D. Horan. 2008. The economics of water quality trading. International Review of Environmental and Resource Economics 2: 101-33.

Smith, M. D. 2007. Generating value in habitat-dependent fisheries: The importance of fishery management institutions. Land Economics 83: 59-73.

Thomas, P., and M. S. Rahman. 2010. Region-wide impairment of Atlantic croaker testicular development and sperm production in the northern Gulf of Mexico hypoxic dead zone. Marine Environmental Research 69: S59-S62. 2012. Extensive reproductive disruption, ovarian masculinization and aromatase suppression in Atlantic croaker in the northern Gulf of Mexico hypoxic zone. Proceedings of Royal Society B 279: 19-27.

Turner, R. E. 2001. Some effects of eutrophication on pelagic and demersal marine food webs. In Coastal hypoxia: Consequences for living resources and ecosystems, ed. N. N. Rabalais, and R. E. Turner. Washington, DC: Coastal and Estuarine Studies 58, American Geophysical Union.

Turner, R. E., N. Qureshi, N. N. Rabalais, Q. Dortch, D. Justić, R. F. Shaw, and J. Cope. 1998. Fluctuating silicate: Nitrate ratios and coastal 
plankton food webs. Proceedings of National Academy of Sciences, USA 95: 13048-51.

Turner, R. E., and N. N. Rabalais. 2013. Nitrogen and phosphorus phytoplankton growth limitation in the northern Gulf of Mexico. Aquatic Microbial Ecology 68: 159-69.

Turner, R. E., N. N. Rabalais, and D. Justić. 2006. Predicting summer hypoxia in the northern Gulf of Mexico: Riverine N, P, and Si loading. Marine Pollution Bulletin 52: 139-48.

2012. Predicting summer hypoxia in the northern Gulf of Mexico: Redux. Marine Pollution Bulletin 64: 319-24.

Turner, R. K., S. Georgiou, I.-M. Gren, F. Wulff, S. Barrett, T. Soderqvist, I. J. Bateman, C. Folke, S. Langaas, T. Zylica, K.-G. Maler, and A.

Markowska. 1999. Managing nutrient fluxes and pollution in the Baltic: An interdisciplinary simulation study. Ecological Economics 30: 333-52. US Department of Agriculture-Natural Resources Conservation Service (USDA-NRCS). 2012. Assessment of the effects of conservation practices on cultivated cropland in the upper Mississippi
River basin. http://www.nrcs.usda.gov/wps/ portal/nrcs/detail/national/technical/nra/ceap/?\&cid=nrcs143_014161 (accessed December 1, 2013). van der Ploeg, R. R., W. Böhm, and M. B. Kirkham. 1999. On the origin of the theory of mineral nutrition of plants and the Law of the Minimum. Soil Science Society of America Journal 63: 1055-62.

Wiseman, W. J., N. N. Rabalais, R. E. Turner, S. P. Dinnel, and A. MacNaughton. 1997. Seasonal and interannual variability within the Louisiana coastal current: Stratification and hypoxia. Journal of Marine Systems 12: 237-48.

Xepapadeas, A. 2011. The economics of non-pointsource pollution. Annual Review of Resource Economics 3: 355-73.

Zimmerman, R. J., and L. M. Nance. 2001. Effects of hypoxia on the shrimp fishery of Louisiana and Texas. In Coastal hypoxia: Consequences for living resources and ecosystems, ed. N. N. Rabalais, and R. E. Turner. Washington, DC: Coastal and Estuarine Studies 58, American Geophysical Union. 